\title{
Calving difficulty influences rumination time and inflammatory profile in Holstein dairy cows
}

\author{
L. M. E. Mammi, ${ }^{1 *} \odot$ D. Cavallini, ${ }^{1} \oplus$ M. Fustini, ${ }^{2} \odot$ I. Fusaro, ${ }^{3} \odot$ M. Giammarco, ${ }^{3} \odot$ A. Formigoni, ${ }^{1} \oplus$ \\ and $\mathrm{A}$. Palmonari ${ }^{1}$ (i) \\ ${ }^{1}$ Department of Veterinary Medical Sciences, University of Bologna, Ozzano dell'Emilia, 40064, Italy \\ ${ }^{2}$ Prevention Department, Provincial Agency for Health of the Autonomous Province of Trento, 38123 Trento, Italy \\ ${ }^{3}$ Faculty of Veterinary Medicine, University of Teramo, Località Piano D’Accio, 64100, Teramo, Italy
}

\begin{abstract}
Difficult calving may adversely affect dairy cow health and performance. Maternal:fetal disproportion is a major cause of dystocia. Therefore, the main objective of this study was to assess the effects of dam: calf body weight ratio (D:C) on calving difficulty, rumination time, lying time, and inflammatory profile in 25 Holstein dairy cows. Using automatic monitoring systems, we monitored behavior and production in 9 primiparous and 16 pluriparous cows between dry-off and $30 \mathrm{~d}$ in milk. During the same period, we collected blood samples to monitor metabolism and inflammatory profile of these cows. Calvings were video recorded to assess calving difficulty and observe the duration of the expulsive stage. After parturition, the cows were separated into 3 classes according to their D:C: easy (E; D:C $>17$ ), medium (M; $14<\mathrm{D}: \mathrm{C}<17$ ), and difficult $(\mathrm{D} ; \mathrm{D}: \mathrm{C}<14)$. The cows in class $\mathrm{D}$ showed relatively longer labor durations (108 min vs. 54 and $51 \mathrm{~min}$ for classes D, M, and E, respectively) and higher calving assistance rates $(50 \%$ vs. 0 and $11 \%$ of calvings for classes $\mathrm{D}, \mathrm{M}$, and $\mathrm{E}$, respectively) than those in the other 2 classes. Compared with the cows in classes $\mathrm{M}$ and $\mathrm{E}$, those in class $\mathrm{D}$ exhibited shorter rumination times on the day of calving $(176 \mathrm{~min} / \mathrm{d}$ vs. 288 and $354 \mathrm{~min} / \mathrm{d}$ for classes $\mathrm{D}, \mathrm{M}$, and $\mathrm{E}$, respectively) and during the first week of lactation $(312 \mathrm{~min} / \mathrm{d}$ vs. 339 and $434 \mathrm{~min} / \mathrm{d}$ for classes $\mathrm{D}, \mathrm{M}$, and E, respectively) and maintained lower rumination values until 30 DIM (399 min/d vs. 451 and $499 \mathrm{~min} / \mathrm{d}$ for classes D, M, and E, respectively). Primiparous class D cows had shorter resting times during the first week after calving compared with those in class M $(8$ vs. $11 \mathrm{~h} / \mathrm{d}$ for classes D and $\mathrm{M}$, respectively). Interclass differences were found in terms of the levels of inflammation markers such as
\end{abstract}

Received May 8, 2020.

Accepted August 15, 2020.

*Corresponding author: ludovica.mammi@unibo.it acute-phase proteins (ceruloplasmin, albumin, retinol, and paraoxonase). Moreover, cows in class D had lower plasma levels of fructosamine and creatinine after calving. Low D:C reduced postcalving rumination time and increased inflammation grade, suggesting a lower welfare of these animals at the onset of lactation. The D:C might serve as a useful index for the identification of cows at relatively higher risk of metabolic and inflammatory disease, thus helping farmers and veterinarians improve the welfare and health of these cows.

Key words: calving difficulty, dairy cow, inflammation, rumination time

\section{INTRODUCTION}

Parturition is one of the most critical moments in the life of a dairy cow. It constitutes the passage from the dry period to lactation and is characterized by dramatic metabolic and hormonal changes that strongly affect dairy cow welfare (Goff and Horst, 1997; Drackley, 1999). Features of an early lactation period include low DMI, negative nutrient balance, and immune dysregulation. These manifestations reduce animal welfare and are markedly influenced by peripartum nutrition, environmental conditions, and stressful or painful events (Goff and Horst, 1997; Drackley, 1999; Bradford et al., 2015). Difficult calving may exacerbate this situation by upregulating the inflammatory response and causing reproductive pathology (Bradford et al., 2015). Dystocia lowers both DMI before calving and milk production and increases the risks of disease and perinatal calf mortality (Mee, 2008; Proudfoot et al., 2009). Calf-to-cow disproportion is a major cause of dystocia (Fiems et al., 2001; Noakes et al., 2001; Mee, 2008) and reduces the calf survival rate (Johanson and Berger, 2003). Low cow-to-calf ratio is typical of double-muscled cattle (Fiems et al., 2001), whereas in dairy cows it is more common in pure Holsteins compared with crossbreeds (Dhakal et al., 2013). Dam: calf mismatch is mainly related to small first-calving 
heifers, male calves, prolonged gestation, and maternal under- and overnutrition during the last month of pregnancy (Mee, 2008). Proudfoot et al. (2009) investigated the effect of a difficult calving on feeding and lying behavior of 22 Holstein cows, from $48 \mathrm{~h}$ before calving to $48 \mathrm{~h}$ after. These authors found that cows with dystocia had different behaviors before calving, such as lower DMI and water intake and higher number of standing bouts. In particular, DMI and standing bouts of cows with dystocia changed significantly $24 \mathrm{~h}$ before calving, suggesting that these behaviors could be useful to discriminate between cows with or without dystocia. On the contrary, Proudfoot et al. (2009) did not find any differences in these behaviors during the $48 \mathrm{~h}$ after calving.

To the best of our knowledge, no studies have attempted to associate calving difficulty and fetal-maternal disproportion with rumination time (RT) and inflammation. Rumination time is considered a sensitive indicator of dairy cow health and is used in automated systems for early disease onset detection (Soriani et al., 2012; Calamari et al., 2014). Here, our hypothesis was that low dam:calf BW ratios (D:C) could negatively influence behavior and inflammation level in dairy cows during the peripartum period, impede cow recovery, and elevate disease risks. Thus, the aim of this study was to investigate the relationship between D:C and rumination, lying time (LT), and inflammatory profile of cows in the first weeks of lactation.

\section{MATERIALS AND METHODS}

The present study was conducted at the teaching dairy farm of the Department of Veterinary Medical Sciences of the University of Bologna (Ozzano Emilia, Italy). During the experiment, the farm housed 85 milking cows in freestalls with straw-bedded cubicles. Their average daily milk production was $32 \pm 1.1 \mathrm{~kg}$. The research was conducted in compliance with Directive 2010/63/EU (European Parliament and Council, 2010) of the European Parliament and the Council of September 22, 2010, on the Protection of Animals Used for Scientific Purposes. The procedures were approved by the Ethical Committee of the Department of Veterinary Medical Sciences of University of Bologna, Italy.

\section{Animals, Housing, and Management}

Twenty-five Holstein cows (9 primiparous and 16 pluriparous) were selected and enrolled in the trial according to their expected calving dates. Behavior, metabolism, and production traits were monitored from dry-off ( $60 \pm 2 \mathrm{~d}$ before calving) to 30 DIM. Primiparous cows were monitored from $60 \mathrm{~d}$ before expected calving date. All calvings occurred between the months of June and August. The temperature-humidity index (THI) was recorded continuously inside the barn by electronic probes (CMP Impianti s.r.l., Viadana Bresciana, Italy). Daily mean THI during the calving period was $75 \pm 3.1$, average minimum THI was $69.7 \pm 3.3$, and average maximum THI was $79.7 \pm 3.1$. During the dry period, the cows were housed in a straw-bedded area, moved to a close-up pen $3 \mathrm{wk}$ before calving, and maintained there until parturition. During the dry period, each animal was allowed $22 \mathrm{~m}^{2}$, of which $9 \mathrm{~m}^{2}$ was a resting area, $5.5 \mathrm{~m}^{2}$ was a feeding area, and $7.5 \mathrm{~m}^{2}$ was external paddock. On average $4 \pm 1 \mathrm{~h}$ after calving, the cows were moved to an early-fresh pen, where they remained for $\geq 10 \mathrm{~d}$, with $10 \mathrm{~m}^{2}$ of straw-bedded area per animal. Depending on their health condition, they were moved to the same milking cow pen. The lactating pen, equipped with 42 straw-bedded cubicles, hosted a total of 40 primiparous and multiparous cows. All dry and milking cow pens were equipped with fans (Vertigo, CMP Impianti s.r.l.). Lactating cows were milked at 0500 and $1800 \mathrm{~h}$ daily in a double-5 herringbone milking parlor equipped with an Afimilk system (Afikim, Kibbutz Afikim, Israel) to measure individual daily milk production $(\mathrm{kg})$ and composition (\% fat, protein, and lactose content) by mid-infrared spectroscopy (Afilab, Afikim). After calving, cow BW was measured twice daily on an automatic weighing scale (Afiweight, Afikim) located at the exit of the milking parlor. The BCS was assessed according to the method of Edmonson et al. (1989) at calving and every $2 \mathrm{wk}$ from dry-off to 30 DIM. During the far-off dry period (from 60 to $21 \mathrm{~d}$ before calving), the cows were fed long grass hay ad libitum. In the close-up pen, they received twice daily for ad libitum consumption a TMR that consisted of chopped grass hay plus $4 \mathrm{~kg}$ of prepartum mix/h per day. The compositions and analyses of the dry and lactating diets are shown in Table 1.

\section{Calving Data}

All calvings were recorded with video cameras in the calving pen for $24 \mathrm{~h} / \mathrm{d}$ to observe calving progress and dam behavior. For each cow, the evolution of the expulsion phase was observed (Noakes et al., 2001). The times of appearance of the amniotic sac and feet, birth, expulsion of the fetal membranes, and any required interventions were recorded. Labor duration was calculated according to the time from the appearance of the amniotic sac or feet to birth. Calving difficulty was assessed according to Schuenemann et al. (2011), who reported timing and evolution of eutocic birth as well as correct calving assistance. Farm personnel were trained to assist cows during calving and intervened 
only when recommended or required to do so. Based on Schuenemann et al. (2011), prolonged labor was defined as time between appearance of the amniotic sac and birth $>60 \mathrm{~min}$. After calving, calf sex and calf and dam BW within $24 \mathrm{~h}$ of delivery were recorded. The D:C, adjusted for BCS $=3.5$ (National Research Council, 2001), was used to retrospectively categorize cows by cluster analysis in 3 classes: easy (E; D:C $>17)$, me$\operatorname{dium}(\mathbf{M} ; 14<\mathrm{D}: \mathrm{C}<17)$, and difficult $(\mathbf{D} ; \mathrm{D}: \mathrm{C}<14)$.

\section{Behavioral Data}

Daily RT (min) were recorded with a Hi-Tag rumination monitoring system (SCR Engineers Ltd., Netanya, Israel) from dry-off to 30 DIM (Schirmann et al., 2009). Resting behavior of each cow was recorded continuously from calving to 30 DIM using a pedometer fitted with an accelerometer (AfiAct, Afimilk Ltd., Kibbutz Afikim, Israel). The minutes and time percentages spent lying per $24 \mathrm{~h}$ were segregated by the software into 24 -h intervals. Resting behavior was characterized as total daily LT (min), percentage of daily LT, and restlessness (calculated as the ratio of daily activity to percentage of daily LT). Characteristics of rumination and resting behaviors were investigated for the various D:C classes.

\section{Blood Analysis}

Blood was sampled from the coccygeal vein between dry-off and 30 DIM at $-30,-15,-5,5,15$, and 30 $\mathrm{d}$ relative to calving $( \pm 1 \mathrm{~d})$. Samples were drawn at

Table 1. Ingredients and chemical composition of dry and lactating cow diets

\begin{tabular}{lcc}
\hline Composition & $\begin{array}{c}\text { Close-up } \\
\text { dry }\end{array}$ & Lactating \\
\hline Ingredient, \% of DM & 70.0 & 39.8 \\
Grass hay & 5.0 & 13.1 \\
Corn flakes & - & 26.7 \\
Sorghum meal & 5.0 & 12.0 \\
Soy meal & - & 6.0 \\
Molasses & - & 2.4 \\
Minerals and vitamin mix ${ }^{2}$ & 20.0 & - \\
Close-up cow mix & & \\
Nutrient, \% of DM & 11.5 & 15.0 \\
CP & 55.2 & 34.2 \\
NDF & 36.3 & 23.9 \\
ADF & 6.4 & 3.0 \\
ADL & 9.5 & 27.3 \\
Starch & 2.3 & 3.1 \\
Ether extract & & \\
\hline
\end{tabular}

${ }^{1}$ Minerals and vitamin mix: $15.6 \% \mathrm{Ca}, 0.1 \% \mathrm{P}, 14.8 \% \mathrm{Na}, 3.3 \% \mathrm{Mg}$, $4,000 \mathrm{mg} / \mathrm{kg} \mathrm{Zn}, 4,000 \mathrm{mg} / \mathrm{kg} \mathrm{Mn}, 500 \mathrm{mg} / \mathrm{kg} \mathrm{Cu}, 50 \mathrm{mg} / \mathrm{kg} \mathrm{I}, 30 \mathrm{mg} /$ $\mathrm{kg}$ Se,700,000 IU/ $\mathrm{kg}$ vitamin A, 50,000 IU/ $\mathrm{kg}$ vitamin $\mathrm{D}_{3}$, and 1,500 $\mathrm{mg} / \mathrm{kg}$ vitamin $\mathrm{E}$.

${ }^{2}$ Close-up cow mix: as fed moisture $12.50 \%$; CP 23.00\%; lipids $2.00 \%$; crude fiber $18.00 \%$; ash $18.50 \%$; $\mathrm{Na} 0.80 \%$; and $\mathrm{Mg} 1.60 \%$.
$0800 \mathrm{~h}$ before TMR distribution using $10-\mathrm{mL}$ Vacuette tubes, each containing $18 \mathrm{IU}$ of $\mathrm{Li}$ heparin $/ \mathrm{mL}$ (Greiner BioOne GmbH, Kremsmünster, Austria). After sampling, the blood was immediately centrifuged at $3,000 \times g$ for $16 \mathrm{~min}$ at $6^{\circ} \mathrm{C}$ to separate the plasma. The plasma was divided into two $1.5-\mathrm{mL}$ portions and stored at $-80^{\circ} \mathrm{C}$ until they were analyzed at Istituto di Zootecnica of the University of Piacenza (Italy) according to the procedures described in Calamari et al. (2016). Plasma metabolites were analyzed at $37^{\circ} \mathrm{C}$ with an automated clinical analyzer (ILAB 600, Instrumentation Laboratory, Lexington, MA). Commercial kits measured glucose, total cholesterol, urea, calcium, total proteins, albumin, globulins, total bilirubin, creatinine, $\gamma$-glutamyltransferase (Instrumentation Laboratory), nonesterified fatty acids (NEFA), zinc (Wako Chemicals GmbH, Neuss, Germany), and BHB (Randox, Antrim, UK). Ceruloplasmin and haptoglobin were determined with reagents prepared according to the methods of Bertoni et al. (2008). Fructosamine was determined using a commercial fructosamine kit (Randox). Total plasma reactive oxygen metabolites, plasma paraoxonase, tocopherol, and retinol were measured as reported by Bionaz et al. (2007).

\section{Statistical Analysis}

The cows were retrospectively separated by cluster analysis into 3 classes representing their D:C: D, M, and $\mathrm{E}$. The data were then compared among these classes. Three cows had incomplete rumination data and therefore were excluded from statistical analysis for RT data. All data were analyzed with JMP Pro v. 15 (SAS Institute Inc., Cary, NC). Data normality was evaluated using a Shapiro-Wilk test. Variables with non-normal distributions were logarithmically or exponentially transformed. A mixed model procedure with repeated measures was used to analyze LT and RT, plasma variables, and milk yield and composition. Plasma variables were aggregated according to the sampling time points: $-30,-15,-5,5,15$, and $30 \mathrm{~d}$. A first-order autoregressive covariance structure was selected according to the Akaike information criterion. Backward elimination was used to choose the best model according to the one with the lowest Akaike information criterion. The final model included D:C class (D, M, or E), days relative to calving, parity (primiparous or pluriparous), and their interactions as fixed effects and the cow as random effect. The terms of the repeated measures were days, and the cow was the subject. When a significant $F$-test for class, class $\times$ DIM, or class $\times$ parity was detected, pairwise means multiple comparisons adjusted by Tukey-Kramer were performed. $P \leq 0.05$ indicated statistically significant 
differences between treatment means. Health events between classes were compared by Fisher's exact test.

\section{RESULTS}

\section{Calving Data}

We monitored 25 calvings over 3 mo. Nine of these were first-calving heifers and 16 were pluriparous. Average D:C of cows included in the study was $16.5 \pm$ 3.27. With cluster analysis, cows were segregated into 3 classes based on their D:C ratio: 8 were classified as D, 8 were classified as $\mathrm{M}$, and 9 were classified as $\mathrm{E}$. The D class was represented mainly by first-calving heifers $(6 / 8)$, whereas none of these animals were in the $\mathrm{E}$ class (Table 2). Cow BW was not different among the 3 classes $(P=0.11)$; they had similar BCS at calving but delivered relatively heavier calves $(P<0.0001$; Table $3)$. The calvings were video recorded, and the entire duration of the expulsive stage was observed without human interference until birth. The expulsive stage was defined as the time from the appearance of the amniotic sac until birth (Noakes et al., 2001; Schuenemann et al., 2011). The average duration of delivery was $71 \mathrm{~min}$. Animals included in class D had the longest duration of labor $(P=0.002)$ and relatively higher assistance rate compared with animals of class $\mathrm{M}$ and $\mathrm{E}(P=0.05)$; in contrast, they had similar length of pregnancy $(P=$ 0.93; Table 3).

\section{Behavioral Data: RT and LT}

All 22 cows for which rumination data were analyzed presented strong reductions in RT on the day of calving. However, the class D cows showed lower RT values than the others (176.3 min vs. 287.8 and $353.7 \mathrm{~min}$ for classes $\mathrm{D}, \mathrm{M}$, and $\mathrm{E}$, respectively; $P=0.012$ ). Primiparous class $\mathrm{D}$ cows had the lowest absolute daily $\mathrm{RT}$ on calving day (154 min; Table 4). A decline of $68 \%$ of the value of $\mathrm{RT}$ recorded before calving (from $-21 \mathrm{~d}$ to $-15 \mathrm{~d}$ ) was observed in cows of class D on calving day, whereas the RT of cows of class E decreased $35 \%(P$ $=0.005)$. Moreover, class D cows maintained lower RT relative to those of class $\mathrm{E}$ and $\mathrm{M}$ after parturition $(P$

Table 2. Distribution of cows (no.) in classes according to their dam: calf $\mathrm{BW}$ ratio (D:C)

\begin{tabular}{lccc}
\hline $\begin{array}{l}\text { D:C } \\
\text { class }^{1}\end{array}$ & $\begin{array}{c}\text { All } \\
\text { animals }\end{array}$ & Primiparous & Pluriparous \\
\hline $\mathrm{D}$ & 8 & 6 & 2 \\
$\mathrm{M}$ & 8 & 3 & 5 \\
$\mathrm{E}$ & 9 & 0 & 9 \\
Total & 25 & 9 & 16 \\
\hline
\end{tabular}

${ }^{1} \mathrm{D}=\mathrm{D}: \mathrm{C}<14 ; \mathrm{M}=\mathrm{D}: \mathrm{C}$ between 14 and $17 ; \mathrm{E}=\mathrm{D}: \mathrm{C}>17$.

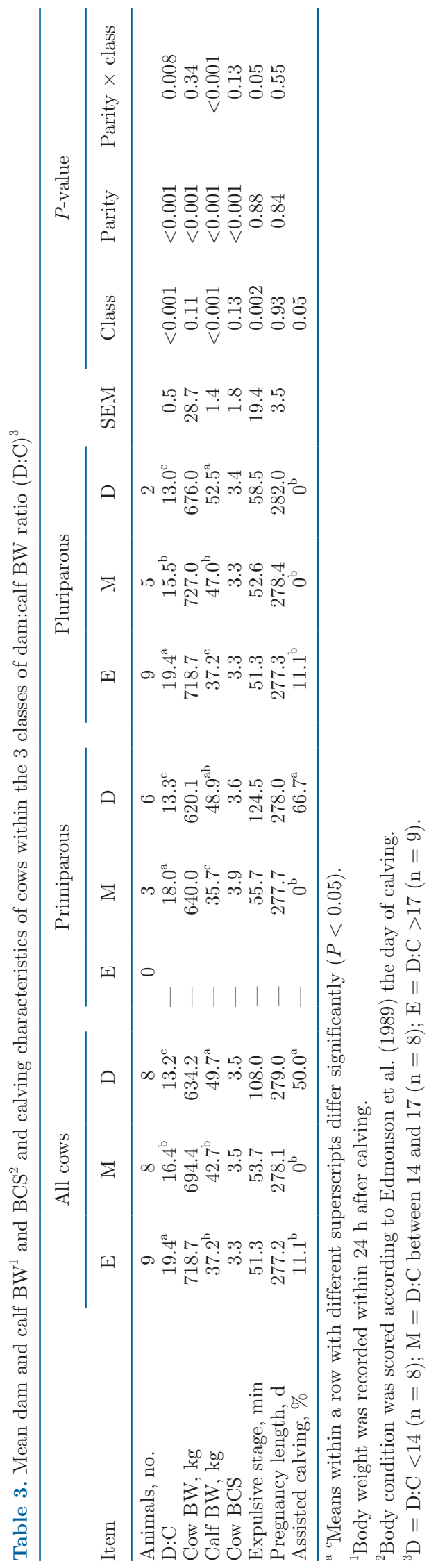


$=0.031 ;$ Figure 1). During the first week of lactation, primiparous class $\mathrm{D}$ cows rested less than those of class $\mathrm{M}(8.6$ vs. $11 \mathrm{~h} / \mathrm{d} ; P=0.04)$. In contrast, pluriparous cows rested $10 \mathrm{~h} / \mathrm{d}$ on average, without differences between animals of class D and those of class E and M. Taking the primiparous and multiparous cows together, no differences $(P=0.83)$ were detected between resting time of class D animals and those of class $\mathrm{E}$ and $\mathrm{M}$ (Table 5).

\section{Blood Variables}

Complete results of plasma analysis before and after calving are reported in Table 6. Figure 2 shows the evolution from $30 \mathrm{~d}$ before calving to 30 DIM of those variables that differed $(P<0.05)$ between classes. Inflammatory phenomena were evident in the class $\mathrm{D}$ cows. These animals showed alterations in certain acute-phase proteins compared with the class E and $\mathrm{M}$ cows. In these animals, the negative acute-phase proteins (albumin, retinol, and paraoxonase) decreased after parturition and remained low until 15 or 30 DIM $(P<0.05)$ Among the positive acute-phase proteins, ceruloplasmin levels at 15 DIM were higher in class $\mathrm{M}$ and $\mathrm{D}$ cows and differed from those in class $\mathrm{E}$ cows $(P=0.002)$. In contrast, haptoglobin peaked $5 \mathrm{~d}$ after calving in all animals and decreased thereafter without differences between classes. Markers of energy status (glucose, NEFA, and BHB) did not differ between animals of different classes, except for fructosamine and creatinine, which were lower $(P=0.02)$ in the class $\mathrm{D}$ cows at 5 and 15 DIM. Conversely, no differences were found in reactive oxygen metabolites, tocopherol, urea, bilirubin, calcium, zinc, $\gamma$-glutamyltransferase, and cholesterol.

\section{Milk Production}

The D:C was not related to milk production or milk composition (Table 7). Class D cows apparently produced less milk than those of classes $\mathrm{M}$ and E. Nevertheless, these data were biased by the comparatively large proportion of primiparous cows in this class. On the other hand, class E was represented exclusively by pluriparous cows. The milk yield was equivalent among the pluriparous cows of all 3 classes, whereas the average milk yields of primiparous cows in classes $\mathrm{M}$ and $\mathrm{D}$ were 26 and $20 \mathrm{~kg} / \mathrm{d}$, respectively $(P=0.10)$.

\section{Health Events}

Complete health event histories are recorded in Table 8. There were only numerical differences among classes $(P>0.05)$. However, $87.5 \%$ of the class $\mathrm{D}$ animals

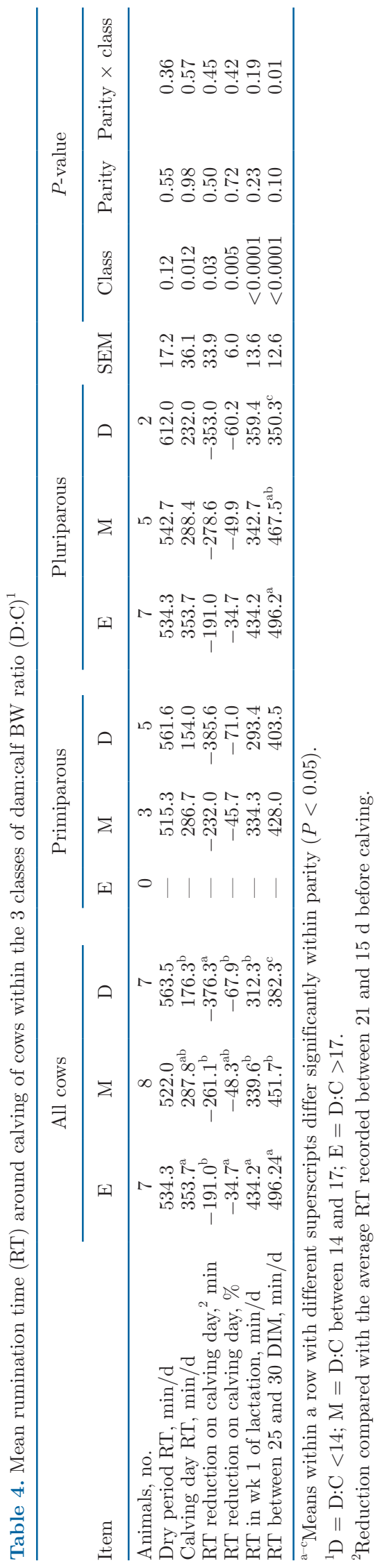


were diagnosed with $\geq 1$ pathology, and only 1 cow in this class reached 30 DIM without any health issues. Conversely, the clinical disease rate in class $\mathrm{E}$ cows was $55.5 \%$.

\section{DISCUSSION}

Cows with lower D:C (class D) had a duration of labor that was more than double compared with animals of other classes (108.0 min vs. 53.7 and $51.3 \mathrm{~min}$ for classes D, M, and E, respectively). Moreover, $50 \%$ of $\mathrm{D}$ cows required delivery assistance. In particular, primiparous cows had the longest average calving time (125 min compared with 59 min for multiparous cows). A previous study reported relatively longer durations for the dilation stage of calving in primiparous cows but no influence of parity on the expulsive phase (Schuenemann et al., 2011). Therefore, D:C and parity are strongly correlated. Here, the heifers had lower $\mathrm{D}$ : C than the multiparous cows. For this reason, the prolonged labor observed in these animals may be ex- plained by dam:calf size mismatch rather than parity per se. Maternal-fetal disproportion is a main cause of dystocia in first-calving heifers (Mee, 2008). It might account for the higher rates of assistance and greater lengths of labor recorded for the class D animals in the present study (Meijering, 1984; Noakes et al., 2001; Mee et al., 2011). Johanson and Berger (2003) found a strong correlation between dystocia and the D:C. For primiparous and multiparous cows, they calculated an average D:C of $7 \%$ and stated that the target ratio was $7.2 \%$ for optimal calf survival (Johanson and Berger, 2003). These values correspond to D:C of 14 . Fiems et al. (2001) reported relatively higher incidences of cesarean sections for cows with an average cow:calf ratio of 11.8. In contrast, those presenting with eutocic births had an average cow:calf ratio of 14.4 (Fiems et al., 2001). According to these authors and considering the longer labor and the higher rate of assistance of cows with lower D:C in the present study, we related the D:C to potential calving difficulty. In particular, D cows (D:C <14) were considered to have a potential dif-

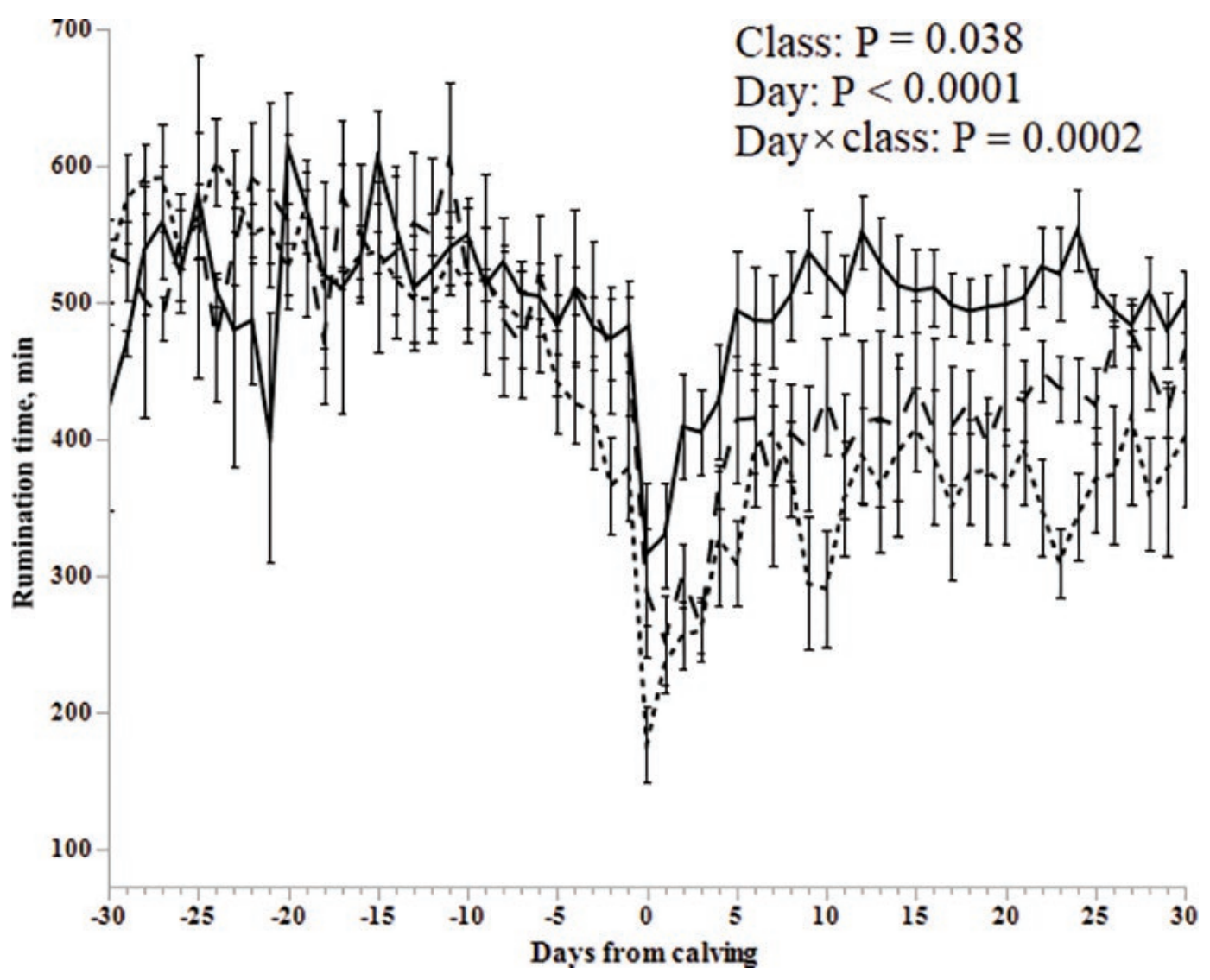

Figure 1. Rumination time (LSM \pm SEM) from $30 \mathrm{~d}$ before calving to 30 DIM in cows belonging to the 3 classes of dam:calf BW ratio (D:C): difficult (D:C <14; 7 cows; dotted line), medium (D:C between 14 and 17; 8 cows; dashed line), and easy (D:C >17; 7 cows; solid line). 


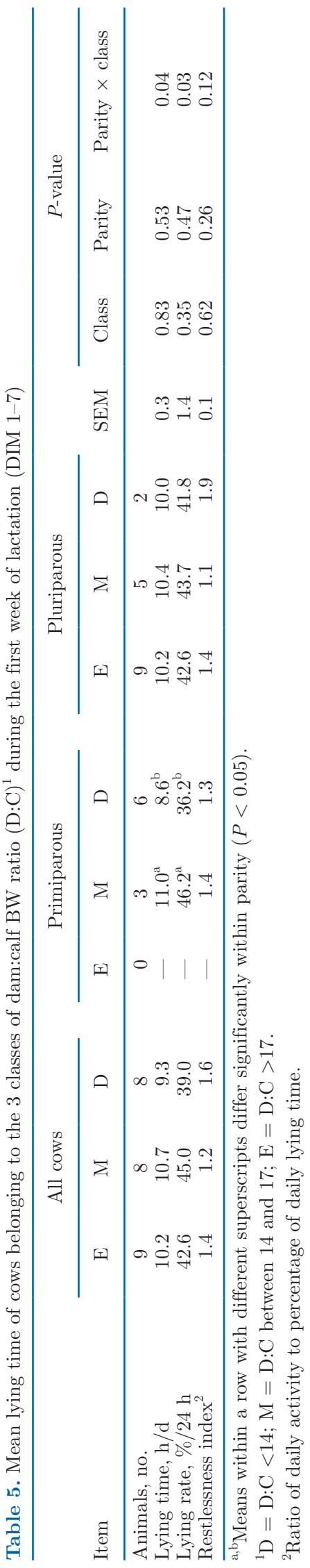

ficult calving, $\mathrm{M}$ cows $(14<\mathrm{D}: \mathrm{C}<17)$ were considered to have a medium calving difficulty, and $\mathrm{E}$ cows (D:C $>17$ ) were considered to have easy calving.

These results confirm the importance of higher BW at calving, particularly for heifers as they require good physical development at first calving (85\% of mature BW) without fattening to avoid dystocia and metabolic diseases (Mee, 2009; Gaafar et al., 2011). Nevertheless, a high BCS at calving must be avoided as it might increase the risk of dystocia by narrowing the birth canal caused via fat deposition as well as the risks of ketosis and other diseases early in lactation (Roche et al., 2009).

Here, class D cows presented with greater relative incidences of retained fetal membranes, metritis, and delay in uterine involution during the peripartum period. We did not evaluate fertility data here as the follow-up period was too short (30 DIM). However, a previous study reported reductions in the fertility indices for cows with veterinary-assisted calvings compared with unassisted cows, including 0.7 more services to conception, $+8 \mathrm{~d}$ to first service, and calving intervals that were 28 d longer (Eaglen et al., 2011). Other authors reported comparatively lower retained fetal membrane incidence and improved conception rates following the administration of nonsteroidal anti-inflammatory drugs within $12 \mathrm{~h}$ of calving (Giammarco et al., 2018).

In the present study, the D:C was related to cow behavior such as LT and RT during the postpartum period. Unexpectedly, evaluation of the lying behavior around calving showed relatively lower resting times for primiparous class D cows during the first week of lactation. On the contrary, we expected an increase in LT for animals with relatively longer and more difficult calving. Increased LT is an illness-related behavior induced by proinflammatory cytokines to promote lethargy and anorexia and accelerate disease recovery (Johnson, 2002; Dantzer and Kelley, 2007). Certain studies report comparatively higher LT for cows affected by clinical or subclinical diseases (Proudfoot et al., 2009; Sepúlveda-Varas et al., 2014). Nevertheless, another study stated that LT was not associated with health status in primiparous animals, although ketotic and sick multiparous cows had longer LT after calving than healthy cows (Piñeiro et al., 2019). Moreover, certain authors reported shorter resting times for primiparous cows than for multiparous cows during the transition period (Sepúlveda-Varas et al., 2014; Neave et al., 2017). Thus, the class D primiparous animals in our study had shorter resting times, possibly because of their lower hierarchical rank. Lactation stage, age, and BW have the strongest influences on social hierarchy (Dickson et al., 1970; Grant and Albright, 1995), and fatigued primiparous cows in early postpartum 
Table 6. Mean plasma variables of cows belonging to the 3 classes of dam:calf BW ratio (D:C $)^{1}$ before (Pre) and after (Post) calving ${ }^{2}$

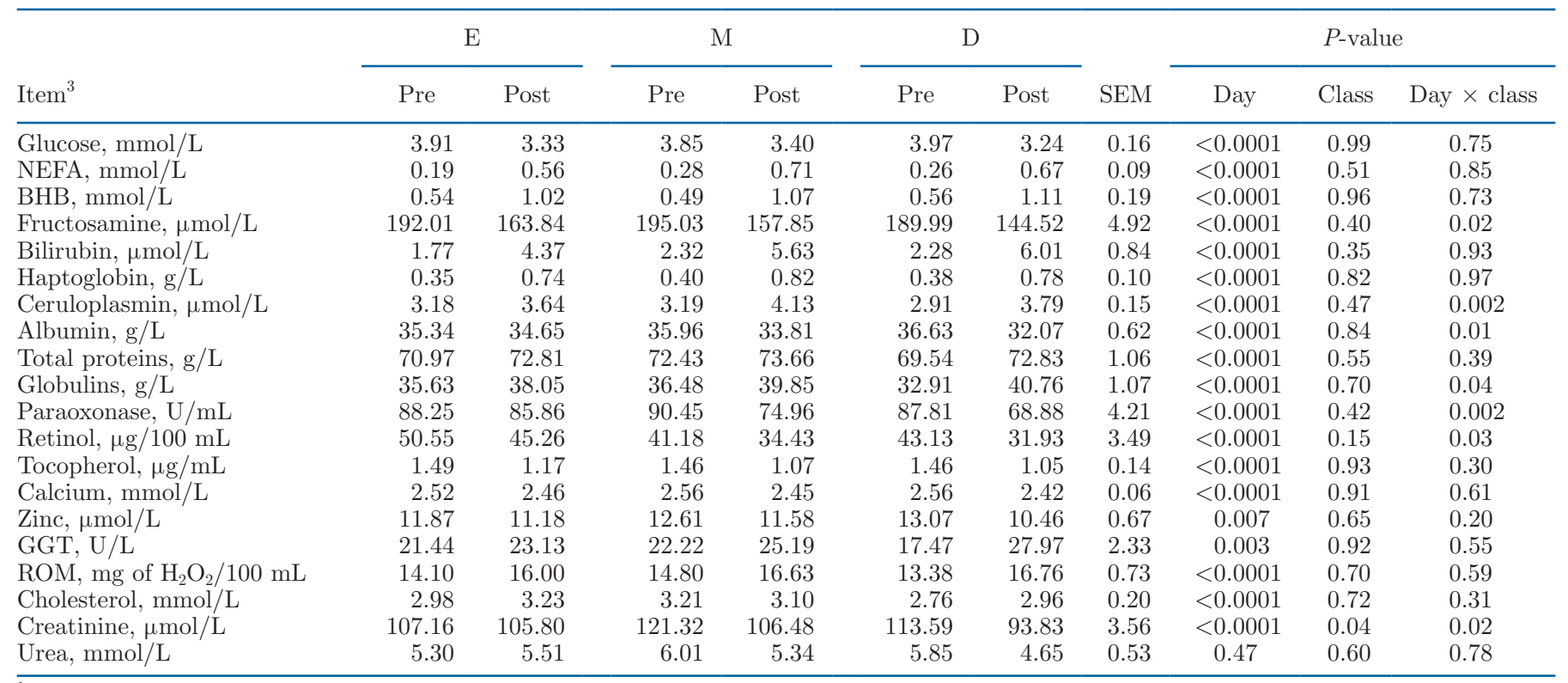

${ }^{1} \mathrm{D}=\mathrm{D}: \mathrm{C}<14(\mathrm{n}=8) ; \mathrm{M}=\mathrm{D}: \mathrm{C}$ between 14 and $17(\mathrm{n}=8) ; \mathrm{E}=\mathrm{D}: \mathrm{C}>17(\mathrm{n}=9)$.

${ }^{2}$ Pre: mean value of samples collected at 30,15 , and $5 \mathrm{~d}$ before calving $( \pm 1)$. Post: mean value of samples collected at 5 , 14 , and $30 \mathrm{~d}$ after calving $( \pm 1)$.

${ }^{3} \mathrm{NEFA}=$ nonesterified fatty acids; GGT $=\gamma$-glutamyltransferase; $\mathrm{ROM}=$ reactive oxygen metabolites.

are the most vulnerable to herd competition (Grant and Albright, 1995; Phillips and Rind, 2001; Cook and Nordlund, 2004; Neave et al., 2017). This situation is commonly reported in overcrowded environments where subordinate cows are often displaced by dominant animals from the feed bunk and spend comparatively more time standing without feeding or resting (Fregonesi et al., 2007). Neave et al. (2017) studied the influence of parity on behavior of healthy cows during transition and reported that, with $80 \%$ stocking density, primiparous cows were displaced by the feeder more frequently than multiparous cows and had more but shorter lying bouts. Excessive standing time could increase the risks of hoof and metabolic disorders around calving. Stressors such as overcrowding and lack of rest upregulate cortisol and dehydroepiandrosterone (Fustini et al., 2017). During early postpartum, adipose tissue is sensitive to stress-related mediators that augment lipolysis and plasma NEFA and increase the risks of metabolic diseases and unsuccessful transition periods (Kushibiki et al., 2002, 2003; Underwood et al., 2003).

Rumination time was markedly reduced in class D animals on the day of calving compared with cows in classes $\mathrm{E}$ and $\mathrm{M}$, and they required relatively more time compared with the other groups to attain optimal RT values after calving (Figure 1). Reductions in RT around calving were reported by several authors who found physiological decreases in RT around parturition. Hence, this behavior could be used to detect the approach of calving (Schirmann et al., 2013; Büchel and Sundrum, 2014; Pahl et al., 2014). A novel aspect of our study is that we analyzed this loss of function with respect to potential calving difficulty. Class D, $\mathrm{M}$, and $\mathrm{E}$ cows had the same rumination values during the dry period. Therefore, the observed low calving day RT and difficulty in attaining physiological values after calving for class D animals might be associated with their difficulty in delivering larger calves and their comparatively longer labor durations. Another study reported lower DMI at 48 and $24 \mathrm{~h}$ before calving in dystocic cows, showing that cows with difficult parturition exhibit distinct feeding and resting behaviors (Proudfoot et al., 2009). These authors explained this observation by changes in the dam:calf ratios that reduce rumen capacity and increase calving pain (Stanley et al., 1993; Proudfoot et al., 2009), preventing animals from feeding and ruminating. Rumination time is influenced by several factors: adequate physically effective NDF in the diet (Mertens, 1997), forage inclusion and composition (Fustini et al., 2011), and diurnal feed availability (Cavallini et al., 2018). Moreover, health disorders, pain, and distress may inhibit rumination; indeed, a decrease in RT is considered a reliable indicator of stress and disease (Soriani et al., 2012; Calamari et al., 2014; Schirmann et al., 2016). Calamari et al. (2014) associated slower increases in RT after calving with severe inflammation, suggesting the importance of monitoring RT after calving to identify cows at rela- 

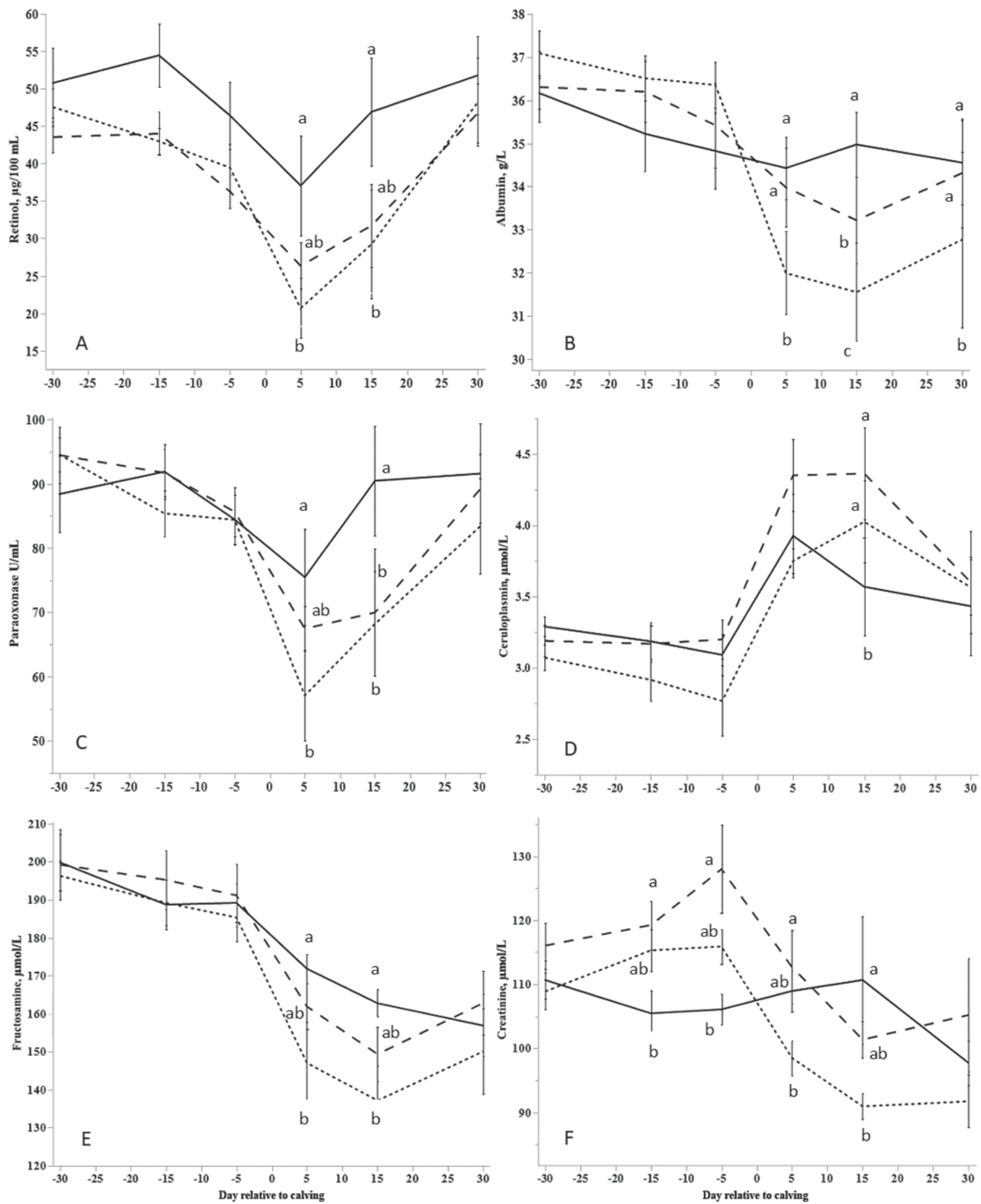

Figure 2. Pattern of plasma variables [retinol (A), albumin (B), paraoxonase (C), ceruloplasmin (D), fructosamine (E), and creatinine (F)] measured from $30 \mathrm{~d}$ before calving to 30 DIM in cows belonging to the 3 classes of dam:calf BW ratio (D:C): difficult (D:C < 14; 7 cows; dotted line), medium (D:C between 14 and 17; 8 cows; dashed line), and easy (D:C >17; 7 cows; solid line). Least squares means \pm SEM are reported. Different letters at the same day indicate significant differences between classes $(P<0.05)$. 
Table 7. Mean milk yield and composition of cows belonging to the 3 classes of dam:calf BW ratio (D:C) ${ }^{1}$ during the first month of lactation

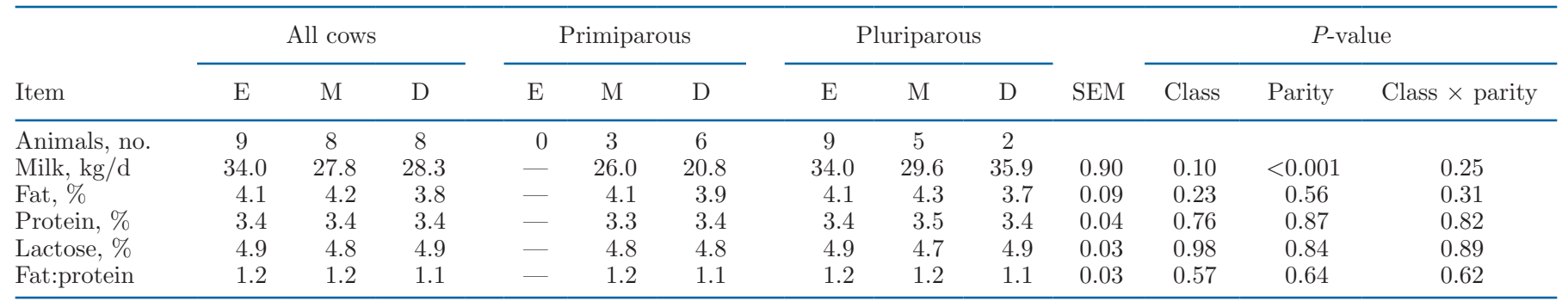

${ }^{1} \mathrm{D}=\mathrm{D}: \mathrm{C}<14 ; \mathrm{M}=\mathrm{D}: \mathrm{C}$ between 14 and $17 ; \mathrm{E}=\mathrm{D}: \mathrm{C}>17$.

tively higher risk of disease (Calamari et al., 2014). The aforementioned study categorized cows as high or low $\mathrm{RT}$ on the basis of their average RT between $\mathrm{d} 3$ and 6 of lactation and found that low-ruminating cows had greater alterations in their acute-phase response than other cows.

Our findings agree with those of Calamari et al. (2014). The D animals, which showed lower RT during and after calving, presented with marked alteration in negative acute-phase proteins and ceruloplasmin, indicating a more severe inflammation process compared with animals of class $\mathrm{E}$ and $\mathrm{M}$. These animals experienced relatively longer and more difficult calvings, which, together with uterine tissue damage, have been previously associated with increased inflammation (Qu et al., 2014; Bradford et al., 2015; Pohl et al., 2015). Interestingly, some authors highlighted a more pronounced inflammation after calving in primiparous cows compared with multiparous cows (Humblet et al., 2006; Schneider et al., 2013; Pohl et al., 2015). These authors speculate that the first calving could drive a more intense acute-phase response compared with following calvings and that primiparous cows could be more sensitive to the stress related to parturition. Our results agree with these studies and show that cows with lower D:C, and therefore particularly primiparous cows, have more severe inflammation in the postpartum period. Thus, we suggest that D:C could be the leading

Table 8. Cases of disease (no.) within 30 DIM of cows belonging to the 3 classes of dam:calf $\mathrm{BW}$ ratio $(\mathrm{D}: \mathrm{C})^{1}$

\begin{tabular}{lcccc}
\hline Item & $\mathrm{E}$ & $\mathrm{M}$ & $\mathrm{D}$ & $P$-value \\
\hline Retained fetal membranes & 1 & 2 & 2 & 0.69 \\
Metritis & 1 & 1 & 2 & 0.82 \\
Delayed uterine involution & 1 & 1 & 2 & 0.82 \\
Ketosis & 3 & 3 & 4 & 0.88 \\
Displaced abomasum & 0 & 1 & 1 & 0.52 \\
Mastitis & 2 & 2 & 0 & 0.50 \\
Absence of pathologies & 4 & 2 & 1 & 0.47 \\
\hline${ }^{1} \mathrm{D}=\mathrm{D}: \mathrm{C}<14(\mathrm{n}=8) ; \mathrm{M}=\mathrm{D}: \mathrm{C}$ between 14 and $17(\mathrm{n}=8) ; \mathrm{E}=$ \\
$\mathrm{D}: \mathrm{C}>17(\mathrm{n}=9)$.
\end{tabular}

cause of the high level of inflammation after calving rather than parity per se.

The energy status markers (glucose, NEFA, and BHB) showed negative energy balance and lipid mobilization characteristic of transition cows without differences among classes, even though fructosamine, which was previously related to the energy balance markers (Caré et al., 2018), was lower in D animals. After calving, cows with lower D:C also exhibited a more pronounced decrease in plasma creatinine compared with other cows, suggesting a higher muscle mobilization in cows of class D compared with cows of class M and E. Plasma creatinine level in healthy, euhydrated cows is strictly related to muscle mass, and it has been recently suggested as a reliable index to monitor protein mobilization in periparturient cows (Wyss and KaddurahDaouk, 2000; Megahed et al., 2019). Therefore, the lower plasma levels of fructosamine and creatinine in $\mathrm{D}$ animals suggest a negative relation of D:C with the energy and protein balance of cows during the postpartum period.

According to the blood indices, however, almost all animals in this study showed alterations in their inflammatory and metabolic profiles. These results confirm the drastic changes typical of transition cows, characterized mainly by metabolic imbalance and inflammatory dysfunction (Sordillo and Raphael, 2013; Bradford et al., 2015).

\section{CONCLUSIONS}

Cows with relatively lower D:C had longer and more difficult calvings. The D:C was negatively related to the RT on the day of calving and during the first month of lactation. Low D:C was also related to lower LT in primiparous cows and higher inflammation markers during the postpartum period as well as lower fructosamine and creatinine. These findings underscore the importance of avoiding excessively heavy calves, especially in first-calving heifers, for which proper physical maturity at breeding is fundamental. The administration of sexed semen could effectively increase the D:C 
in smaller heifers. Moreover, fetus sex and size detection during pregnancy and cow BCS monitoring might help identify cows at comparatively higher risk of health problems. Adverse physiological alterations postpartum can mitigate cow welfare and increase the risk of unsuccessful transitions. The present study considered only the first $30 \mathrm{~d}$ of lactation, and the long-term consequences of calving difficulty are far from clear.

\section{ACKNOWLEDGMENTS}

This work was supported by the Department of Veterinary Medical Science of the University of Bologna (Bologna, Italy). The authors declare no conflict of interest.

\section{REFERENCES}

Bertoni, G., E. Trevisi, X. Han, and M. Bionaz. 2008. Effects of inflammatory conditions on liver activity in puerperium period and consequences for performance in dairy cows. J. Dairy Sci. 91:33003310. https://doi.org/10.3168/jds.2008-0995.

Bionaz, M., E. Trevisi, L. Calamari, F. Librandi, A. Ferrari, and G. Bertoni. 2007. Plasma paraoxonase, health, inflammatory conditions, and liver function in transition dairy cows. J. Dairy Sci. 90:1740-1750. https://doi.org/10.3168/jds.2006-445.

Bradford, B. J., K. Yuan, J. K. Farney, L. K. Mamedova, and A. J. Carpenter. 2015. Invited review: Inflammation during the transition to lactation: New adventures with an old flame. J. Dairy Sci. 98:6631-6650. https://doi.org/10.3168/jds.2015-9683.

Büchel, S., and A. Sundrum. 2014. Short communication: Decrease in rumination time as an indicator of the onset of calving. J. Dairy Sci. 97:3120-3127. https://doi.org/10.3168/jds.2013-7613.

Calamari, L., A. Ferrari, A. Minuti, and E. Trevisi. 2016. Assessment of the main plasma parameters included in a metabolic profile of dairy cow based on Fourier transform mid-infrared spectroscopy: Preliminary results. BMC Vet. Res. 12:4. https://doi.org/10.1186/ s12917-015-0621-4.

Calamari, L., N. Soriani, G. Panella, F. Petrera, A. Minuti, and E. Trevisi. 2014. Rumination time around calving: An early signal to detect cows at greater risk of disease. J. Dairy Sci. 97:3635-3647. https://doi.org/10.3168/jds.2013-7709.

Caré, S., E. Trevisi, A. Minuti, A. Ferrari, J. J. Loor, and L. Calamari. 2018. Plasma fructosamine during the transition period and its relationship with energy metabolism and inflammation biomarkers in dairy cows. Livest. Sci. 216:138-147. https://doi.org/10.1016/j .livsci.2018.08.003.

Cavallini, D., L. M. E. Mammi, M. Fustini, A. Palmonari, A. J. Heinrichs, and A. Formigoni. 2018. Effects of ad libitum or restricted access to total mixed ration with supplemental long hay on production, intake, and rumination. J. Dairy Sci. 101:10922-10928. https://doi.org/10.3168/jds.2018-14770.

Cook, N. B., and K. V. Nordlund. 2004. Behavioral needs of the transition cow and considerations for special needs facility design. Vet. Clin. North Am. Food Anim. Pract. 20:495-520. https://doi.org/ 10.1016/j.cvfa.2004.06.011.

Dantzer, R., and K. W. Kelley. 2007. Twenty years of research on cytokine-induced sickness behavior. Brain Behav. Immun. 21:153-160. https://doi.org/10.1016/j.bbi.2006.09.006.

Dhakal, K., C. Maltecca, J. P. Cassady, G. Baloche, C. M. Williams, and S. P. Washburn. 2013. Calf birth weight, gestation length, calving ease, and neonatal calf mortality in Holstein, Jersey, and crossbred cows in a pasture system. J. Dairy Sci. 96:690-698. https://doi.org/10.3168/jds.2012-5817.
Dickson, D. P., G. R. Barr, L. P. Johnson, and D. A. Wieckert. 1970. Social dominance and temperament of Holstein cows. J. Dairy Sci. 53:904-907. https://doi.org/10.3168/jds.S0022-0302(70)86316-0.

Drackley, J. K. 1999. Biology of dairy cows during the transition period: The final frontier? J. Dairy Sci. 82:2259-2273. https://doi .org/10.3168/jds.s0022-0302(99)75474-3.

Eaglen, S. A. E., M. P. Coffey, J. A. Woolliams, R. Mrode, and E. Wall. 2011. Phenotypic effects of calving ease on the subsequent fertility and milk production of dam and calf in UK Holstein-Friesian heifers. J. Dairy Sci. 94:5413-5423. https://doi.org/10.3168/ jds.2010-4040.

Edmonson, A. J., I. J. Lean, L. D. Weaver, T. Farver, and G. Webster. 1989. A body condition scoring chart for Holstein dairy cows. J. Dairy Sci. 72:68-78. https://doi.org/10.3168/jds.S0022 -0302(89)79081-0.

European Parliament and Council. 2010. Directive 2010/63/EU of the European Parliament and of the Council of 22 September 2010 on the protection of animals used for scientific purposes. Off. J. Eur. Union L, 276, 20.10.2010, pages 33-79. http://data.europa.eu/eli/ $\operatorname{dir} / 2010 / 63 /$ oj.

Fiems, L. O., S. de Campeneere, W. van Caelenbergh, and C. V. Boucqué. 2001. Relationship between dam and calf characteristics with regard to dystocia in Belgian Blue double-muscled cows. Anim. Sci. 72:389-394. https://doi.org/10.1017/S1357729800055880.

Fregonesi, J. A., C. B. Tucker, and D. M. Weary. 2007. Overstocking reduces lying time in dairy cows. J. Dairy Sci. 90:3349-3354. https: //doi.org/10.3168/jds.2006-794.

Fustini, M., G. Galeati, G. Gabai, L. E. Mammi, D. Bucci, M. Baratta, P. A. Accorsi, and A. Formigoni. 2017. Overstocking dairy cows during the dry period affects dehydroepiandrosterone and cortisol secretion. J. Dairy Sci. 100:620-628. https://doi.org/10.3168/jds 2016-11293

Fustini, M., A. Palmonari, E. Bucchi, A. J. Heinrichs, and A. Formigoni. 2011. Chewing and ruminating with various forage qualities in nonlactating dairy cows. Prof. Anim. Sci. 27:352-356. https:// doi.org/10.15232/S1080-7446(15)30499-X.

Gaafar, H. M. A., Sh. M. Shamiah, M. A. A. El-Hamd, A. A. Shitta, and M. A. T. El-Din. 2011. Dystocia in Friesian cows and its effects on postpartum reproductive performance and milk production. Trop. Anim. Health Prod. 43:229-234. https://doi.org/10 $.1007 / \mathrm{s} 11250-010-9682-3$.

Giammarco, M., I. Fusaro, G. Vignola, A. C. Manetta, A. Gramenzi, M. Fustini, A. Palmonari, and A. Formigoni. 2018. Effects of a single injection of Flunixin meglumine or Carprofen postpartum on haematological parameters, productive performance and fertility of dairy cattle. Anim. Prod. Sci. 58:322-331. https://doi.org/ 10.1071/AN16028.

Goff, J. P., and R. L. Horst. 1997. Physiological changes at parturition and their relationship to metabolic disorders. J. Dairy Sci. 80:1260-1268. https://doi.org/10.3168/jds.S0022-0302(97)76055 -7 .

Grant, R. J., and J. L. Albright. 1995. Feeding behavior and management factors during the transition period in dairy cattle. J. Anim. Sci. 73:2791-2803. https://doi.org/10.2527/1995.7392791x.

Humblet, M.-F., H. Guyot, B. Boudry, F. Mbayahi, C. Hanzen, F. Rollin, and J.-M. Godeau. 2006. Relationship between haptoglobin, serum amyloid A, and clinical status in a survey of dairy herds during a 6-month period. Vet. Clin. Pathol. 35:188-193. https:// doi.org/10.1111/j.1939-165x.2006.tb00112.x.

Johanson, J. M., and P. J. Berger. 2003. Birth weight as a predictor of calving ease and perinatal mortality in Holstein cattle. J. Dairy Sci. 86:3745-3755. https://doi.org/10.3168/jds.S0022 $-0302(03) 73981-2$

Johnson, R. W. 2002. The concept of sickness behavior: A brief chronological account of four key discoveries. Vet. Immunol. Immunopathol. 87:443-450. https://doi.org/10.1016/s0165-2427(02)00069 -7 .

Kushibiki, S., K. Hodate, H. Shingu, Y. Obara, E. Touno, M. Shinoda, and Y. Yokomizo. 2003. Metabolic and lactational responses during recombinant bovine tumor necrosis factor- $\alpha$ treatment in 
lactating cows. J. Dairy Sci. 86:819-827. https://doi.org/10.3168/ jds.S0022-0302(03)73664-9.

Kushibiki, S., K. Hodate, H. Shingu, T. Hayashi, E. Touno, M. Shinoda, and Y. Yokomizo. 2002. Alterations in lipid metabolism induced by recombinant bovine tumor necrosis factor-alpha administration to dairy heifers. J. Anim. Sci. 80:2151-2157. https://doi . .org/10.2527/2002.8082151x.

Mee, J. F. 2008. Prevalence and risk factors for dystocia in dairy cattle: A review. Vet. J. 176:93-101. https://doi.org/10.1016/j.tvjl 2007.12.032.

Mee, J. F. 2009. Bovine perinatology: Current understanding and future developments. Pages 67-106 in Animal Reproduction: New Research Developments. L. T. Dahnof, ed. Nova Science Publishers, Hauppauge, NJ.

Mee, J. F., D. P. Berry, and A. R. Cromie. 2011. Risk factors for calving assistance and dystocia in pasture-based Holstein-Friesian heifers and cows in Ireland. Vet. J. 187:189-194. https://doi.org/ 10.1016/j.tvjl.2009.11.018.

Megahed, A. A., M. W. H. Hiew, D. Ragland, and P. D. Constable. 2019. Changes in skeletal muscle thickness and echogenicity and plasma creatinine concentration as indicators of protein and intramuscular fat mobilization in periparturient dairy cows. J. Dairy Sci. 102:5550-5565. https://doi.org/10.3168/jds.2018-15063.

Meijering, A. 1984. Dystocia and stillbirth in cattle-A review of causes, relations and implications. Livest. Prod. Sci. 11:143-177. https://doi.org/10.1016/0301-6226(84)90057-5.

Mertens, D. R. 1997. Creating a system for meeting the fiber requirements of dairy cows. J. Dairy Sci. 80:1463-1481. https://doi.org/ 10.3168/jds.S0022-0302(97)76075-2.

National Research Council. 2001. Nutrient Requirements of Dairy Cattle. 7th rev. ed. National Academies Press, Washington, DC.

Neave, H. W., J. Lomb, M. A. G. von Keyserlingk, A. Behnam-Shabahang, and D. M. Weary. 2017. Parity differences in the behavior of transition dairy cows. J. Dairy Sci. 100:548-561. https://doi.org/ 10.3168/jds.2016-10987.

Noakes, D. E., T. J. Parkinson, and G. C. W. England. 2001. Dystocia due to fetomaternal disproportion: Treatment. Pages 279-289 in Arthur's Veterinary Reproduction and Obstetrics. 8th ed. Saunders, Philadelphia, PA.

Pahl, C., E. Hartung, A. Grothmann, K. Mahlkow-Nerge, and A. Haeussermann. 2014. Rumination activity of dairy cows in the 24 hours before and after calving. J. Dairy Sci. 97:6935-6941. https:/ /doi.org/10.3168/jds.2014-8194.

Phillips, C. J. C., and M. I. Rind. 2001. The effects on production and behavior of mixing uniparous and multiparous cows. J. Dairy Sci. 84:2424-2429. https://doi.org/10.3168/jds.S0022-0302(01)74692 -9 .

Piñeiro, J. M., B. T. Menichetti, A. A. Barragan, A. E. Relling, W. P. Weiss, S. Bas, and G. M. Schuenemann. 2019. Associations of pre- and postpartum lying time with metabolic, inflammation, and health status of lactating dairy cows. J. Dairy Sci. 102:3348-3361. https://doi.org/10.3168/jds.2018-15386.

Pohl, A., O. Burfeind, and W. Heuwieser. 2015. The associations between postpartum serum haptoglobin concentration and metabolic status, calving difficulties, retained fetal membranes, and metritis. J. Dairy Sci. 98:4544-4551. https://doi.org/10.3168/jds.2014-9181.

Proudfoot, K. L., J. M. Huzzey, and M. A. G. von Keyserlingk. 2009. The effect of dystocia on the dry matter intake and behavior of Holstein cows. J. Dairy Sci. 92:4937-4944. https://doi.org/10 $.3168 /$ jds.2009-2135.

Qu, Y., A. N. Fadden, M. G. Traber, and G. Bobe. 2014. Potential risk indicators of retained placenta and other diseases in multiparous cows. J. Dairy Sci. 97:4151-4165. https://doi.org/10.3168/jds.2013 -7154 .

Roche, J. R., N. C. Friggens, J. K. Kay, M. W. Fisher, K. J. Stafford, and D. P. Berry. 2009. Invited review: Body condition score and its association with dairy cow productivity, health, and welfare. J. Dairy Sci. 92:5769-5801. https://doi.org/10.3168/jds.2009-2431.

Schirmann, K., N. Chapinal, D. M. Weary, L. Vickers, and M. A. G. von Keyserlingk. 2013. Short communication: Rumination and feeding behavior before and after calving in dairy cows. J. Dairy Sci. 96:7088-7092. https://doi.org/10.3168/jds.2013-7023.

Schirmann, K., M. G. von Keyserlingk, D. M. Weary, D. M. Veira, and W. Heuwieser. 2009. Technical note: Validation of a system for monitoring rumination in dairy cows. J. Dairy Sci. 92:6052-6055. https://doi.org/10.3168/jds.2009-2361.

Schirmann, K., D. M. Weary, W. Heuwieser, N. Chapinal, R. L. A Cerri, and M. A. G. von Keyserlingk. 2016. Short communication: Rumination and feeding behaviors differ between healthy and sick dairy cows during the transition period. J. Dairy Sci. 99:99179924. https://doi.org/10.3168/jds.2015-10548.

Schneider, A., M. N. Corrêa, and W. R. Butler. 2013. Short communication: Acute phase proteins in Holstein cows diagnosed with uterine infection. Res. Vet. Sci. 95:269-271. https://doi.org/10.1016/j .rvsc.2013.02.010.

Schuenemann, G. M., I. Nieto, S. Bas, K. N. Galvão, and J. Workman. 2011. Assessment of calving progress and reference times for obstetric intervention during dystocia in Holstein dairy cows. J. Dairy Sci. 94:5494-5501. https://doi.org/10.3168/jds.2011-4436.

Sepúlveda-Varas, P., D. M. Weary, and M. A. G. von Keyserlingk. 2014. Lying behavior and postpartum health status in grazing dairy cows. J. Dairy Sci. 97:6334-6343. https://doi.org/10.3168/ jds.2014-8357.

Sordillo, L. M., and W. Raphael. 2013. Significance of metabolic stress, lipid mobilization, and inflammation on transition cow disorders. Vet. Clin. North Am. Food Anim. Pract. 29:267-278. https://doi .org/10.1016/j.cvfa.2013.03.002.

Soriani, N., E. Trevisi, and L. Calamari. 2012. Relationships between rumination time, metabolic conditions, and health status in dairy cows during the transition period. J. Anim. Sci. 90:4544-4554. https://doi.org/10.2527/jas.2011-5064.

Stanley, T. A., R. C. Cochran, E. S. Vanzant, D. L. Harmon, and L. R. Corah. 1993. Periparturient changes in intake, ruminal capacity, and digestive characteristics in beef cows consuming alfalfa hay. J. Anim. Sci. 71:788-795. https://doi.org/10.2527/1993.713788x.

Underwood, J. P., J. K. Drackley, G. E. Dahl, and T. L. Auchtung. 2003. Responses to epinephrine challenges in peripartal Holstein cows fed two amounts of metabolizable protein in prepartum diets. J. Dairy Sci. 86(Suppl. 1):106. (Abstr.)

Wyss, M., and R. Kaddurah-Daouk. 2000. Creatine and creatinine metabolism. Physiol. Rev. 80:1107-1213. https://doi.org/10.1152/ physrev.2000.80.3.1107.

\section{ORCIDS}

L. M. E. Mammi ๑ https://orcid.org/0000-0002-7344-0686

D. Cavallini $\odot$ https://orcid.org/0000-0002-1642-6722

M. Fustini () https://orcid.org/0000-0001-9069-0866

I. Fusaro $\odot$ https://orcid.org/0000-0002-2532-7240

M. Giammarco @ https://orcid.org/0000-0002-9256-8685

A. Formigoni ( https://orcid.org/0000-0002-8109-2482

A. Palmonari @ https://orcid.org/0000-0003-3735-8826 